\title{
Dobro - Prawda - Piękno w sztuce naszego czasu
}

\author{
Good - Truth - Beauty \\ in the Contemporary Art
}

„Ty uzdalniasz artystów,

aby swym talentem ukazywali Twoje piękno, niechaj ich dzieła budzą w świecie nadzieję i radość".

(Modlitwa brewiarzowa, III Tydzień)

W obiegowym znaczeniu zdolności i talent są dla artysty czymś naturalnym i oczywistym. Tymczasem na sukces artystyczny, choćby najmniejszy, składa się oprócz nieuchwytnego talentu także praca. Praca wytężona, systematyczna i bezinteresowna. Ta bezinteresowność w sztuce jest podstawą wszelkiej twórczej działalności. Artysta tworząc nie powinien myśleć o końcowym rezultacie ani o uznaniu i ewentualnym zysku materialnym. Nie stworzy dzieła wartościowego i prawdziwego ten, kto jest interesowny. Prawda jest podstawą i warunkiem w sztuce, zarówno w muzyce, plastyce, poezji, teatrze czy architekturze. Bez niej dzieło zawsze będzie bezwartościowe.

Ojcowie II Soboru Watykańskiego skierowali do artystów wezwanie: „Świat potrzebuje piękna, aby nie pogrążyć się w rozpaczy. Piękno, podobnie jak prawda, budzi radość w ludzkich sercach 
i jest cennym owocem, który trwa mimo upływu czasu, tworzy więź między pokoleniami i łączy je w jednomyślnym podziwie"1.

Dzieło sztuki, jeżeli jest autentyczne (a więc wynika z prawdziwej, odszukiwanej uparcie treści i formy), może pomagać w dostępie do głębszej rzeczywistości, może pośredniczyć na drodze do wiary. $\mathrm{Z}$ jednej więc strony dzieło sztuki należy traktować jako propozycję dialogu, z drugiej - warto wierzyć, że dzieło sztuki, postawa artysty, forma i treść mogą być narzędziem wychowania człowieka, rozmową ze współczesnymi, która zawsze pozostaje aktualna.

Søren Kierkegaard, znakomity duński filozof, twierdził, że: „Niepewności człowiek przezwyciężyć nie zdoła, prawdy obiektywnej nigdy nie doścignie, a najwyżej osiągnie subiektywne jej poczucie”. Kierkegaard mówił więc, że „prawda jest subiektywna” albo, że „subiektywność jest prawdą”2. Blaise Pascal zauważył natomiast, że: „Pożądamy prawdy, a znajdujemy jedynie nędzę i śmierć. [...] a nie jesteśmy zdolni ani do pewności, ani do szczęścia”. Wiele wieków wcześniej św. Augustyn zanotował: „Wejdź w siebie, we wnętrzu człowieka mieszka prawda"4. Platońska triada Dobra, Prawdy i Piękna dotyczy wszelkich dziedzin sztuki. Już Platon pisał, że: „Potęga Dobra schroniła się w naturze Piękna”’ Wynika stąd, że są one integralnie ze sobą powiązane. Jedno wynika $z$ drugiego, aby połączyć się z terminem trzecim. Dlatego mówi się, że wszelka trójca jest doskonała. Każde dzieło sztuki, malarskie, rzeźbiarskie, muzyczne czy literackie (poezja) jest w pewnym sensie wyzwoleniem osobowości. Sztuka jest obszarem uczuć - jest emocją, która dba o dobrą i właściwą formę. Ostateczne wartości sztuki wykraczają poza jednostkę, poza jej czasy i warunki istnienia ${ }^{6}$.

W historycznym znaczeniu „sztuka” długo oznaczała tyle, co umiejętność wytwarzania zgodnego z regułami jakichkolwiek rzeczy.

Jan Paweł II, List do artystów, Watykan 1999, s. 28.

2 W. Tatarkiewicz, Historia filozofii, t. 3: Filozofia XIX wieku i wspótczesna, Warszawa 1958, s. 89.

3 B. Pascal, Myśli, przeł. T. Żeliński (Boy), Warszawa 1953, s. 152.

4 W. Tatarkiewicz, Parerga, Warszawa 1978, s. 133.

5 Jan Paweł II, List do artystów, dz. cyt., s. 9.

$6 \quad$ H. Read, Sens sztuki, przeł. K. Tarnowska, Warszawa 1965, s. 12. 
Od XIX wieku pojmowana jest jako umiejętność wytwarzania rzeczy estetycznie wartościowych, pięknych, wstrząsających czy nowych.

Forma dzieła oznacza jego jakość. Treść jest ukazywaniem przez artystę tego, co pragnie przekazać swojemu odbiorcy. Forma jest więc również rezultatem przeżyć artysty w procesie twórczym tego, co jest sensem jego duchowości. Piękno jest rozumiane dwojako: jako naturalne bądź też jako przydane - znaczy to, że jedne ciała są piękne $\mathrm{z}$ natury, inne stają się piękne przez włożone w nie starania ${ }^{7}$. For ma to przeżyty kształt. Istnieje jednak piękno samej formy, niezależnie od życiowych czy uczuciowych kojarzeń, wzniosłości czy wdzięku - to piękno proporcji i liczb. Platon powiadał, że piękno jest boskim (théion) pierwiastkiem, a renesansowy pisarz Baldassare $\mathrm{Ca}^{-}$ stiglione nazwał piękno „świętym” (sacra bellezza). Cyprian K. Norwid natomiast uważał, że piękno jest wszędzie - zapewne chodziło mu o wdzięk czy wzniosłość ${ }^{8}$. Historia dowodzi trwałej wartości klasycznych rzeźb i świątyń greckich. Nie jest też konieczne, aby wszystkie wartości były w równym stopniu obiektywne czy subiektywne. Wartość ma obraz Jana Vermeera, wartość ma także zblakła fotografia. Obraz ma wartość ze względu na barwę i kształt, fotografia ze względów sentymentalnych ${ }^{9}$. Istniejąca hierarchia wskazuje, że obok wartości estetycznych jest także miejsce w sztuce na wartości poznawcze i moralne.

Tym co łączy estetykę nie jest ani piękno, ani sztuka, lecz p r z eżycie estetyczne, któremu bliska jest kontemplacja dzieł plastycznych, muzycznych czy literackich, zwłaszcza poezji. Sztuka jest wyrazem ekspresji przeżyć, uczuć, radości i cierpienia. Dzieło powstaje $\mathrm{w}$ procesie twórczym, który łączy w sobie wzruszenie, jakość intelektualną i talent artysty ${ }^{10}$. Człowiek będąc bytem jednolitym otwiera się na sztukę, dobro, piękno. Istotne jest, aby posiadać dystans wobec otoczenia i siebie. W wychowaniu należy pamiętać i stosować w praktyce humor i uśmiech. „Humor pozwala przełamywać bariery społeczne, skracać dystans, obniża intensywność

\footnotetext{
W. Tatarkiewicz, Parerga, dz. cyt., s. 16-19.

Tamże, s. 15.

9 Tamże, s. 66-67.

10 Tamże, 91-92
} 
przeżyć lękowych i ułatwia kontakty międzyosobowe”11. „Tworząc wychowawczo atmosferę humoru, ułatwiamy w pewnych granicach realizację procesów twórczych" ${ }^{\prime 2}$. Proces twó r c zy powstaje poprzez wzruszenie, poznanie, analizę, syntezę - postrzeganie koloru, kształtu, przestrzeni oraz światła i mroku. Jest informacją otaczającej nas rzeczywistości. Prawdziwy, autentyczny artysta nie zabiega o sukces za wszelką cenę. Sukces artystyczny jest konsekwencją i rezultatem rzetelnej pracy. Tajemnica procesu twórczego jest istotą sztuki. Różna też bywa droga twórcza poszczególnych artystów. Jedni dochodzą do sławy w młodości a inni w wieku podeszłym, a jeszcze inni, jak np. Vincent van Gogh, po śmierci.

Na przykład Stanisław Wyspiański umiera mając zaledwie 37 lat a jego dorobek poetycki, plastyczny i dramatyczny wystarczyłby na kilku artystów. Projektował meble i witraże. Jeździł do Wiednia, aby dopilnować realizacji witraży według swojego projektu. Natomiast Jan Matejko zmarł w wieku 55 lat. Był krótkowidzem, nie ukończył szkoły średniej, ponieważ był mało zdolnym uczniem. Malował fragmentami, kratkując płótno. Dlatego też nie zobaczył w całości niektórych swoich obrazów. Mimo tego ich kompozycja i proporcje są doskonałe. Zważywszy na jego krótkie życie, liczba jego znakomitych obrazów jest ogromna. Także Vermeer, podobnie jak wielu innych malarzy, za życia był niedoceniony. Po jego śmierci żona musiała spłacać obrazami długi nawet w piekarni. Van Gogh za życia sprzedał tylko jeden obraz. Po jego śmierci mąż siostry zamierzał spalić około pięciuset obrazów znajdujących się na strychu, ponieważ zajmowały zbyt dużo miejsca. Partytury Ludwiga van Bethovena są pokreślone, widać były ciągle poprawiane. Natomiast u Wolfganga Amadeusza Mozarta wyglądają jak wydrukowane, bez śladu skreśleń czy poprawek.

Znamienne jest, że osoba otwarta na rozmaite zjawiska w świecie, intelektualnie poszukująca, posiadająca wyobraźnię, zaciekawiona filozofią i religią, tolerancyjna - taka osoba będzie czerpać z życia i ze sztuki więcej aniżeli ci, którzy w samozadowoleniu wolą zamknąć

\footnotetext{
11 C. Matusewicz, Humor, dowcip, wychowanie. Analiza psychospoteczna, Warszawa, 1976, s. 105-131.

12 Tamże, s. 147.
} 
swój umysł. Jakże często słychać wypowiedzi artykułowane z pewnego rodzaju wyższością: „Ja się na sztuce nie znam. Na współczesnych wynalazkach, owszem - tak, ale sztuka jest poza obszarem moich zainteresowań". Jest to prosta droga do barbarzyństwa, którego wokó1 nie brakuje. A przecież sztukę należy przeżywać i odczuwać, tak jak powinno się dzięki empatii przeżywać cierpienie drugiego człowieka czy zwierzęcia. Przeżycie estetyczne prowadzi do wrażliwości i duchowości. Nasza cywilizacja powstała dzięki chrześcijaństwu. O ileż bardziej uboga byłaby sztuka bez świątyń katolickich, ich wystroju, rzeźb, witraży czy samej architektury. Znam przykłady, że studenci mieszkający w Krakowie nie byli w kościele Mariackim w Rynku. Karygodny brak zainteresowania sztuką wcześniej czy później doprowadzi do katastrofy ducha.

Sztuka polska na tle sztuki światowej posiada niezwykłe przykłady malarstwa, np. nigdzie poza Polską nie spotykamy portretów trumiennch. W okresie baroku w Polsce wykształcił się w kulturze katolickiej zwyczaj malowania portretów osób zmarłych. Na blasze cynowej malowano portrety kobiet, mężczyzn, rzadziej dzieci. Dotyczyło to najczęściej osób pochodzenia szlacheckiego. Portrety trumienne należą do jedynej w swoim rodzaju, oryginalnej kreacji polskiej kultury barokowej i nie występują nigdzie poza obszarami Rzeczypospolitej. Oczywiste, że zainteresowanie sztuką oraz uczestniczenie $\mathrm{w}$ rozmaitych formach wydarzeń artystycznych czynią z czasem człowieka wrażliwym nie tylko na piękno, ale także na dobro i prawdę.

Edukację estetyczną należy rozpoczynać bardzo wcześnie. Chodzi o to, aby nie tylko okazyjnie patrzeć na dzieła sztuki, słuchać muzyki i ją przeżywać - należy to czynić często. Bez treningu, pewnej żmudnej, szarej powtarzalności nie ma efektów. Sztuka „zabiera” nas w rejony odległe od smutnej czasem i nudnej codzienności, uskrzydla, uspokaja, choć czasem też irytuje i smuci, ale jest terapią najbardziej ze wszystkich skuteczną. To rodzaj k o n te m placji zbliżonej do przeżywania kontaktu $\mathrm{z}$ transcendencją. Aby to osiągnąć, trzeba sztukę traktować podobnie jak pokarm, czyli rzecz niezbędną do życia, w tym wypadku - do życia duchowego. Jakże to smutne kiedy obserwuje się studentów zwiedzających muzeum, którzy oglądając wspaniałe, piękne dzieła sztuki wydają się znudzeni i wręcz zniecierpliwieni. Trudno się dziwić, skoro kontakt bezpośredni z obrazami 
mają po raz pierwszy lub drugi w swoim życiu. Percepcja sztuki dotyczy również myślenia, o czym w ogóle się nie mówi. „Myśl stanowi wielkość człowieka” - tak pisał Pascal, dodając, że „człowiek jest w przyrodzie wątłą trzciną, ale myślącą"13. Analizując dzieje sztuki przez pokolenia, od prehistorii poprzez starożytność, średniowiecze, renesans, barok aż do współczesności, widoczny jest ogromny zakres i różnorodność emocji, talentu, ale nade wszystko pracy artystów. Wraz ze zmieniającymi się epokami dochodziły do głosu różnice w kompozycji, kolorze, formie i treści. Sztuka z dekoracyjnej stawała się z czasem problemową i kształcącą. Od realizmu przechodziła do abstrakcji i deformacji natury, w celu większej ekspresji oddziaływania na odbiorcę. Po rewolucyjnym impresjonizmie nastąpił kubizm, ekspresjonizm i tak aż do czasów obecnych, w których występuje pełna dowolność. Obecnie mniej liczy się perfekcja formy i kompozycji czy koloru, lecz bardziej konieczność zaszokowania widza. Widomo że sztuka i jej jakość są konsekwencjami i odzwierciedleniem osobowości i duchowości artystów. Poprzez swoją jakość sztuka powinna kształcić, uspokajać, ale również niepokoić, zmuszać odbiorcę do refleksji i zamyślenia, także nad własnym życiem. Ważne aby człowiek wykształcony był również ukształtowany poprzez sztukę, filozofię, religię a nawet politykę.

Sztuka w Polsce przeobrażała się i zmieniała w zależności od epoki. Inna była w XV wieku, inna podczas zaborów, w okresie międzywojennym a jeszcze inna w stanie wojennym (1981-1983) oraz po odzyskaniu niepodległości po roku 1989. Artyści plastycy, aktorzy, muzycy, poeci, literaci w okresie stanu wojennego protestowali wobec ówczesnej sytuacji. W ramach protestu konsekwentnie nie uczestniczyli w oficjalnym (państwowym) życiu kulturalnym. Przenieśli swoją twórczość plastyczną, muzyczną i aktorską do kościołów i prywatnych pomieszczeń, czasem również do mieszkań. Była to sytuacja bez precedensu. Niezwykle ważną rolę odegrała hierarchia i księża Kościoła katolickiego. Powstała kultura niezależna w Kościele. Szczególnie prężnymi ośrodkami były: Warszawa, Kraków, Wrocław, Poznań, Gdańsk, Katowice i inne miasta. Zaczęto organizować wówczas Tygodnie Kultury Chrześcijańskiej, które opierały się głównie na wystawach plastycznych, wieczorach poetyckich i li- 
terackich $\mathrm{w}$ świątyniach, połączone $\mathrm{z}$ koncertami muzyki religijnej lub poważnej. Tygodnie te gromadziły ogromne rzesze uczestników. Powstające prace plastyczne miały charakter aluzyjny, poetycki i polityczny. Ich artystyczna jakość była wysoka, wskazywała na duchowy proces twórczy artystów. Mimo tego sztuka tamtych lat nie była dokumentacją politycznych przeżyć, ale duchową reakcją na dramat ówczesnej Polski. Szczególnym zjawiskiem była widoczna solidarność między artystami, zarówno tymi wierzącymi, jak i tymi, którzy wcześniej byli poza Kościołem. Wielu z nich dzięki takim działaniom artystycznym powróciło na łono Kościoła. Ks. Jan Sochoń tak pisze o tym czasie: „Owa «podziemna Ojczyzna» dawała siłę, wzmacniała nadzieję, że osiągalne są prawda i szczęście, a czołgi i broń nie są w stanie pokonać miłości, patriotycznych uniesień i wiary. Drogi przemocy nie trwają wiecznie..." ${ }^{14}$.

Minęło wiele lat, a w naszym szkolnictwie wychowanie przez sztukę nie uległo żadnej poprawie. Zamiast nauki o sztuce podnoszone są wątpliwości, czy w ogóle warto się tym zajmować? Coraz bardziej rozprzestrzenia się agresja, nie tylko na ulicy, ale także w szkołach, choć czasem nauczyciele nie chcą tego zauważać. Komputerowe gry i programy telewizyjne są przesiąknięte agresją. Niestety dorośli nie zawsze potrafią w mądry sposób temu zapobiegać. Aby przywrócić właściwą kolej rzeczy i hierarchię wartości, jest nam w tym bardzo potrzebna sztuka. „Piękno, które utożsamia się z dobrem, jest zatem miarą, proporcją, prawdą a także cnotą (w greckim sensie tego słowa, czyli doskonałym urzeczywistnieniem istoty rzeczy). [...] Tylko Pięknu to właśnie przypadło w udziale, że ono jest najokazalsze i najbardziej godne umiłowania" (Fajdros 250 D-E)"15. Szczególnie w dziejach Polski - w czasach pokoju, wojen, przemian społecznych i politycznych - to sztuka stanowi swoisty portret naszych dziejów.

14 J. Sochoń, Mój dom, mój bliźni, moja Ojczyzna... Zapiski wiary, „Ethos”1997, nr 4(40), s. 183.

15 G. Reale, Utrata poczucia formy. Platon i ontologiczny wymiar piękna, przeł. J. Merecki, „Ethos”1997, nr 4(40), s. 65. 
Jan Paweł II, List do artystów, Drukarnia Watykańska, Watykan 1999.

Matusewicz C., Humor, dowcip, wychowanie. Analiza psychospołeczna, "Nasza Księgarnia”, Warszawa 1976.

Pascal B., Myśli, przeł. T. Żeliński (Boy), PAX, Warszawa 1953.

Read H., Sens sztuki, przeł. K. Tarnowska, PWN, Warszawa 1965.

Reale G., Utrata poczucia formy. Platon i ontologiczny wymiar piękna, przeł. J. Merecki, „Ethos” 1997, $\mathrm{nr}$ 4(40).

Sochoń J., Mój dom, mói bliźni, moja Ojczyzna... Zapiski wiary, „Ethos” 1997, nr 4(40).

Tatarkiewicz W., Historia filozofii, t. 3: Filozofia XIX wieku i współczesna, PWN, Warszawa 1958.

Tatarkiewicz W., Parerga, PWN, Warszawa 1978.

\section{STRESZCZENIE SUMMARY}

W obiegowym znaczeniu zdolności i talent sq dla artysty czymś naturalnym i oczywistym. Tymczasem na sukces artystyczny, choćby najmniejszy, składa się oprócz nieuchwytnego talentu także praca. Praca wytężona, systematyczna i bezinteresowna. Ta bezinteresowność w sztuce jest podstawq wszelkiej twórczej działalności. Każde dzieło sztuki, malarskie, rzeźbiarskie, muzyczne czy literackie (poezja) jest w pewnym sensie wyzwoleniem osobowości. Sztuka jest obszarem uczuć - jest emocja która dba o dobra i właściwa formę. Sztuka powinna poprzez swoja jakość kształcić, uspokajać, ale również niepokoić, zmuszać odbiorcę do refleksji i zamyślenia, także nad własnym życiem. Ważne aby człowiek wykształcony był również ukształtowany poprzez sztukę, filozofię, religię a nawet politykę. Historia dowodzi trwałej wartości klasycznych rzeźb i świq̨tyń greckich. Nie jest też konieczne, aby wszystkie wartości były $w$ równym stopniu obiektywne czy subiektywne. Sztuka w Polsce prze-
It is a common assumption that for an artist abilities and talent are something natural and obvious. However, what contributes to an artistic success, even the smallest one, apart from intangible talent is also work. This kind of work is painstaking, systematic and selfless. This selflessness in art is the basis of any artistic activity. Every work of art, painting, sculpture, music or literature (poetry) is, in a sense, the liberation of personality. Art is the realm of emotions - it is an emotion, which cares about its good and proper form. Art should, through its quality, educate, pacify but, at the same time, disturb, it should make us think and ponder on our lives as well. It is significant that an educated man should also be shaped through art, philosophy, religion and even politics. History proves the permanent value of classic sculpture and Greek temples. It is not necessary for all values to be equally either objective or subjective. Art in Poland transformed itself and changed depending on the era. It was different in the 15th century, different during the partitions, in the interwar period and different during the Martial Law (19811983) as well as after Poland regained independence after 1989. Although many years have passed, education through art in our educational system has not improved. Instead of teaching art, doubts are raised whether it is worth dealing 
with art at school at all. On the other hand, aggression is spreading on a greater scale, not only in the street but also at schools, yet sometimes many teachers fail to notice that. To restore the proper order of things as well as the hierarchy of values art is indispensable.

\section{ADRES DO KORESPONDENCJI:}

prof. dr hab. Irena Popiołek

Katedra Edukacji Artystycznej

Akademia Ignatianum w Krakowie

ul. Kopernika 26

31-501 Kraków obrażała się i zmieniała w zależności od epoki. Inna była w XV wieku, inna podczas zaborów, w okresie międzywojennym, a jeszcze inna w stanie wojennym (1981-1983) oraz po odzyskaniu niepodległości po roku 1989. Minęło wiele lat, a wychowanie przez sztukę w naszym szkolnictwie nie uległo żadnej poprawie. Zamiast nauki ○ sztuce panuje wątpliwość czy w ogóle warto się tym zajmować? Agresja natomiast coraz bardziej rozprzestrzenia się, nie tylko na ulicy, ale także w szkołach, choć nauczyciele czasem nie chcq tego zauważać. Aby przywrócić właściwq kolej rzeczy i hierarchię wartości, sztuka jest nam w tym bardzo potrzebna. 
